\title{
Evaluation of Indoor Environmental Quality and Health Concerns in a Juvenile Court
}

Building

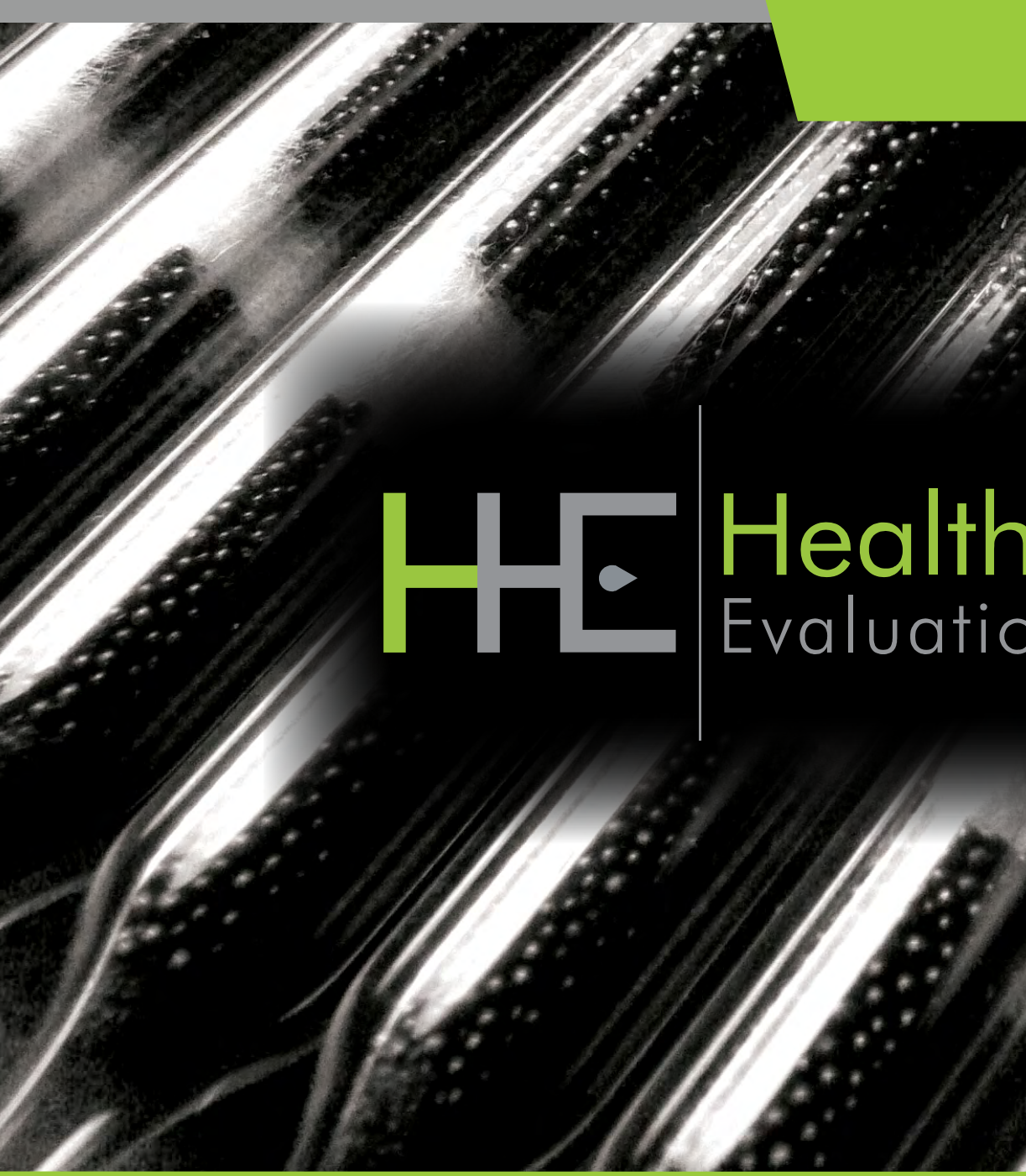

HHE Report No. 2015-0183-3255

June 2016

Elena Page, MD, MPH Jessica F. Li, MSPH Sophia Chiu, MD, MPH Kendra Broadwater, MPH Gregory Burr, CIH 


\section{Contents}

Highlights.

Abbreviations ...................................... iii

Introduction ................................... 1

Methods .............................................. 1

Results ................................................. 3

Discussion ........................................... 7

Conclusions......................................... 10

Recommendations.......................... 10

Appendix A ....................................... 12

References ......................................... 17

Acknowledgements........................... 23

The employer is required to post a copy of this report for 30 days at or near the workplace(s) of affected employees. The employer must take steps to ensure that the posted report is not altered, defaced, or covered by other material.

The cover photo is a close-up image of sorbent tubes, which are used by the HHE Program to measure airborne exposures. This photo is an artistic representation that may not be related to this Health Hazard Evaluation. Photo by NIOSH. 


\section{Highlights of this Evaluation}

The Health Hazard Evaluation Program received an employer request from a juvenile court. Employees were concerned about exposure to raw sewage and diesel odors in the building. We made a site visit in November 2015.

\section{What We Did}

- We did a walk-through survey of courtrooms, offices, detention areas, basement mechanical rooms, and the roof.

- We looked for moisture, water damage, sewage, and mold. We also sampled for hydrogen sulfide (also called sewer gas).

- We measured carbon dioxide, temperature, and relative humidity.

- We measured airflow in offices and employee restrooms.

- We looked at the ventilation for the building.

- We interviewed employees. We asked about their work, medical history, and work-related health concerns.

\section{What We Found}

- We did not see widespread signs of water damage or mold. We did see water leaks that the juvenile court managers were aware of in pod B and the public defender's office.

- An underground diesel storage tank next to the building complied with state regulations.

- We did not smell sewer gas or detect hydrogen sulfide in air.

We evaluated indoor environmental quality in a juvenile court. We saw no widespread mold, water damage, or sewage problems. We detected no sewer gas. An underground diesel storage tank, a concern to some employees, complied with state regulations. Temperatures in occupied areas were not within recommended comfort guidelines, and the ventilation system had deficiencies. Many symptoms reported by employees have been associated with buildings or inadequate ventilation, but are also common in the general population. We recommended a comprehensive ventilation assessment.

- Carbon dioxide levels were high in some offices.

This means that the ventilation did not provide enough outdoor air throughout the work day.

- Temperatures in offices and courtrooms were not within recommended comfort guidelines.

- No air was flowing from ceiling diffusers in the parentage office.

- No supply or exhaust air was flowing in employee restrooms.

- None of the air handling units had visible evidence of microbial growth.

- Air filters were clean and properly installed in all air handling units except unit 4. That unit had a small (1 inch) gap between the air filters and the filter frame. 
- Technicians did not have a ventilation test and balance report or an up-to-date set of building drawings that accurately showed ventilation system components.

- Cast iron waste pipes under the building's foundation were corroded but repair plans were proceeding.

- Detainees reportedly flushed objects to intentionally clog the building's sewage system.

- Although we did not link employees' symptoms and illnesses directly to the building, some nonspecific symptoms are likely related to poor ventilation.

- We found no evidence that health problems such as cancer, gallstones, and thyroid problems were related to working in the building.

\section{What the Employer Can Do}

- Hire a licensed professional mechanical engineer to assess the ventilation systems.

- Encourage employees to report water leaks, water damage, or raw sewage to the building's maintenance staff.

- Consider installing grinders or other types of controls in the building's sewage system.

- Create a system for employees to report building concerns and to receive feedback on how issues were resolved.

- Stop environmental sampling for chemical and biological causes of health symptoms.

\section{What Employees Can Do}

- Report work-related health concerns to juvenile court managers.

- See an occupational medicine physician about health problems you think may be related to work.

- Recognize that some symptoms may not have a medical diagnosis.

- Join the indoor environmental quality committee. 


\section{Abbreviations}

$\begin{array}{ll}\text { ANSI/ASHRAE } & \text { American National Standards Institute/ASHRAE } \\ \mathrm{CO}_{2} & \text { Carbon dioxide } \\ \mathrm{EPA} & \text { Environmental Protection Agency } \\ \text { IARC } & \text { International Agency for Research on Cancer } \\ \text { IEQ } & \text { Indoor environmental quality } \\ \mathrm{NIOSH} & \text { National Institute for Occupational Safety and Health } \\ \mathrm{RH} & \text { Relative humidity }\end{array}$


This page left intentionally blank 


\section{Introduction}

The Health Hazard Evaluation Program received a request from the employer at a juvenile court and detention building. Employees thought cancer and other health issues including thyroid problems, gallstones, kidney stones, strokes, intestinal issues, immune system problems, burning eyes, headaches, and nausea might be related to exposure to raw sewage, leaks from an underground diesel storage tank, and mold from a May 2010 flood. During our November 2015 site visit, we met with juvenile court administrators, employee representatives, representatives from the county health department, and staff responsible for maintaining the ventilation systems in the building. We also did an environmental and health assessment.

\section{Background}

An indoor environmental quality (IEQ) evaluation was conducted in September 2010 (after remediation for the flood) by a consultant the judicial court managers hired. The evaluation included carbon dioxide $\left(\mathrm{CO}_{2}\right)$, carbon monoxide, temperature, and relative humidity $(\mathrm{RH})$ sampling; passive air sampling for aldehydes and volatile organic compounds; and surface (10 square centimeters) swab samples for Escherichia coli and Enterococcus bacteria. No carbon monoxide was found; temperature and RH levels were within recommended ANSI (American National Standards Institute)/ASHRAE comfort guidelines; and $\mathrm{CO}_{2}$ concentrations were within recommended ANSI/ASHRAE IEQ ventilation guidelines. Aldehydes (with limits of detection of $<0.03$ to $<0.04$ parts per million) and volatile organic compounds (with limits of detection of $<0.07$ to $<0.48$ parts per million) were not detected. Surface swab samples were negative for bacteria.

A new judge who came to the bench in the fall of 2014 asked her staff to interview current employees about their work environment. The judge learned that many employees had building-related health concerns that they associated with potential exposure to raw sewage, leaks from an underground diesel storage tank, and mold from the May 2010 flood. Some of the recurrent sewage backups in the building were from detainees purposely flushing items such as jumpsuits.

A structural examination of the building by a consultant discovered corroded cast iron waste pipes that could result in sewage leaking beneath the concrete slab foundation. In December 2014, the judicial court managers did air testing for volatile organic compounds and hired a consultant to test the drinking water. Air samples for volatile organic compounds were taken in the public defenders' office and intake/pretrial area. Drinking water samples were taken from the first floor men's restroom and a second floor water fountain. Acetone, isopropyl alcohol, and methylene chloride were detected in the air samples in very low concentrations (parts per billion range). Drinking water results were within acceptable limits, with the majority of regulated and unregulated contaminants below their limits of detection.

\section{Methods}

Our objectives for this evaluation were to answer the following questions:

1. Does the building have a mold, sewage, or other IEQ problem? 
2. Are employees reporting work-related health effects that are known to be associated with mold or sewage exposures or other aspects of IEQ?

\section{Environmental Assessment}

Our walk-through survey included courtrooms, offices, detention areas, and locations not readily accessible to employees, such as the basement mechanical rooms and the roof. We checked floor drains for visual evidence of sewage. We measured for airborne hydrogen sulfide (sewer gas) near the drains using a direct-reading MultiRAE® Lite portable gas monitor. We also reviewed information on the underground diesel storage tank next to the building that provided fuel for emergency back-up electrical generators.

In addition to looking for water damage and potential mold contamination, we checked for hidden moisture using the following instruments:

- A FLIR ${ }^{\circledR}$ TG165 imaging infrared thermometer. We used this device to screen for potentially moist or water-damaged areas in surfaces such as walls, floors, and ceilings. It uses infrared thermal imaging technology to detect temperature differences. It identifies dry and wet materials, even materials that are not readily visible, such as behind drywall or above a suspended ceiling.

- A TRAMEX Moisture Encounter Plus nondestructive moisture meter. This handheld direct-reading device can measure the interior wall moisture levels. We used the moisture meter to confirm if suspected moist areas identified by the infrared thermometer were actually moist.

We measured $\mathrm{CO}_{2}$, temperature, and RH over 1.5 days using calibrated TSI Q-Trak ${ }^{\mathrm{TM}}$ Indoor Air Quality monitors. We also measured temperature and RH using Onset HOBO ${ }^{\circledR}$ Pro data loggers. We selected locations with varying occupancy levels throughout the work day, such as in the juvenile courtrooms. We also selected locations in the basement and on the first and second floors because they were ventilated by different air handing systems. We measured indoor and outdoor $\mathrm{CO}_{2}$ concentrations to determine if indoor occupied spaces are adequately ventilated [ANSI/ASHRAE 2016]. We measured temperature and RH because they can affect how employees perceive their indoor environment [ANSI/ASHRAE 2013]. Excessive humidity can also promote the growth of microorganisms and dust mites.

We reviewed building drawings and discussed the design, operation, and maintenance of the ventilation systems with the ventilation maintenance staff. We measured airflow in offices and restrooms using a calibrated Alnor Balometer ${ }^{\circledR}$ capture hood. We used ventilation smoke tubes to visualize airflow direction in offices and restrooms.

\section{Employee Interviews and Medical Record Review}

We interviewed all available employees in the building about medical conditions or symptoms they thought were related to conditions or exposures in the building. We took a medical history to identify unrecognized occupational illness. Medical records were requested if employees reported seeing a physician for health issues that they attributed 
to conditions in the building. We did not request medical records for health problems we determined were not related to the building, such as gallbladder disease.

\section{Results}

\section{Environmental Assessment}

\section{Building Description and Walk-through Survey}

The three-story brick and masonry building was built in 1993; 134 employees worked there at the time of our evaluation. The administrative side included offices and courtrooms that operated between 8:00 a.m. and 4:30 p.m.; the detention side operated 24 hours per day, 7 days per week. Most of the administrative office and courtroom areas were carpeted. The flooring on the detention side was primarily tile or sealed concrete. Since 1993 the building had undergone renovations to accommodate more employees, mainly by converting storage spaces to restrooms, individual offices, and office cubicles. Following a flood in May 2010 the basement was renovated, and the ventilation ducts serving these areas were cleaned and sanitized. The detention area had a rated capacity of 86 beds and housed about 30 juvenile inmates at the time of our evaluation.

We saw no evidence of past or current sewage around floor drains. We did not detect hydrogen sulfide (also called sewer gas) during this evaluation. The lowest concentration of hydrogen sulfide that can be detected varies from person-to-person but has been estimated to be as low as 0.2 parts per billion. This concentration is well below the limit of detection of many direct-reading instruments [ATSDR 1999; Nordic Council of Ministers 2001; Van Aalst et al. 2000]. Therefore, collecting air samples for hydrogen sulfide may not be useful because you can smell it at levels lower than it can often be measured. Although we did not smell sewer odors during our survey, because hydrogen sulfide can paralyze the nerves associated with your sense of smell over time (your olfactory system), its odor is not a reliable warning signal [Hathaway and Proctor 2004]. The building has trap primers that automatically add water to maintain water seals in traps. The trap primers prevent sewer gases from entering the building. We did not notice fragrance odors in most areas of the building.

One underground diesel tank is outside the building on the southeast side. The tank can store 1,000 gallons of diesel fuel and is inspected monthly by the state. It complies with the state's petroleum underground storage tank act, passing its last inspection in March 2015. The vent for the underground diesel tank is at ground level and not near the rooftop outdoor air intakes for the building's air handling units.

We focused our moisture and mold assessment in the basement because of the 2010 flood. We saw no widespread evidence of water damage or mold growth. We saw water leaks near an exterior door in the pod B common areas of the detention center and under a sink faucet in the public defender's office. The building managers were aware of the leaks, and both were scheduled for repair. Using the thermal imaging thermometer, we found that exterior walls on the basement level that were partially or completely below grade were cooler than nearby walls. After checking these walls with the moisture meter we found the surfaces were not wet 
or damp. We saw no evidence of poor drainage or standing water on the exterior of the building.

\section{Carbon Dioxide, Temperature, and Relative Humidity Measurements}

Table 1 summarizes the $\mathrm{CO}_{2}$ concentrations, temperature, and $\mathrm{RH}$ levels measured in courtrooms and offices over 1.5 days. Figure 1 shows the $\mathrm{CO}_{2}$ levels throughout the work day in courtroom $\mathrm{H}$. We are displaying results for courtroom $\mathrm{H}$ because they are representative of the other courtrooms and eight office areas where $\mathrm{CO}_{2}$ levels exceeded outdoor levels by at least 700 parts per million. The $\mathrm{CO}_{2}$ levels typically began increasing after lunch and continued to increase throughout the afternoon.

Table 1. Carbon dioxide, temperature, and relative humidity measurements

\begin{tabular}{lcccc}
\hline Dates & Location & $\begin{array}{c}\mathrm{CO}_{2} \text {, } \\
\text { parts per million } \\
\text { (range) }\end{array}$ & $\begin{array}{c}\text { Temperature } \\
\text { (range) }\end{array}$ & $\begin{array}{c}\% \mathrm{RH} \\
\text { (range) }\end{array}$ \\
\hline $11 / 16 / 15-11 / 17 / 15$ & Community probation & $630-1,100$ & $70-72^{*}$ & $44-50$ \\
& Court clerk (back) & $570-1,200 \dagger$ & $72-75^{*}$ & $39-44$ \\
& Courtroom D & $530-1,300 \dagger$ & $70-73^{*}$ & $39-54$ \\
& Courtroom H & $490-1,500 \dagger$ & $69-72^{*}$ & $43-53$ \\
& Intake (front) & $510-1,400 \dagger$ & $71-73^{*}$ & $38-50$ \\
& Parentage & $520-1,400 \dagger$ & $71-73^{*}$ & $41-49$ \\
$11 / 17 / 15-11 / 18 / 15$ & $490-1,300 \dagger$ & $65-70^{*} \ddagger$ & $49-56$ \\
& Public defender & $650-1,100$ & $67-70^{*} \ddagger$ & $46-51$ \\
& Child protective services & $510-1,400 \dagger$ & $71-74^{*}$ & $46-52$ \\
& Court clerk (front) & $500-1,100$ & $71-74^{*}$ & $49-58$ \\
& Courtroom A & $430-1,400 \dagger$ & $71-74^{*}$ & $48-58$ \\
& Courtroom I & $510-1,500 \dagger \S$ & $71-75^{*}$ & $46-53$ \\
& Intake (back) & $470-1,300 \dagger$ & $67-71^{*} \ddagger$ & $51-61$ \\
Patdoor & Parole & $460-1,420 \dagger$ & $72-79^{*} \ddagger$ & $41-54$ \\
& Security & $370-380$ & & \\
\hline
\end{tabular}

${ }^{*}$ Temperatures were not within recommended thermal comfort guidelines for the summer $\left(75^{\circ} \mathrm{F}-81^{\circ} \mathrm{F}\right)$ [ANSI/ASHRAE 2013].

†The maximum indoor $\mathrm{CO}_{2}$ concentrations exceeded outdoor concentrations by at least 700 parts per million. This suggests that the ventilation system(s) was not providing enough outdoor air to maintain acceptable ventilation throughout the work day [ANSI/ASHRAE 2016].

$\ddagger$ Temperatures were not within recommended thermal comfort guidelines for the winter $\left(68^{\circ} \mathrm{F}-77^{\circ} \mathrm{F}\right)$ [ANSI/ASHRAE 2013].

$\S$ The Q-Trak monitor lost power during the sampling period. 


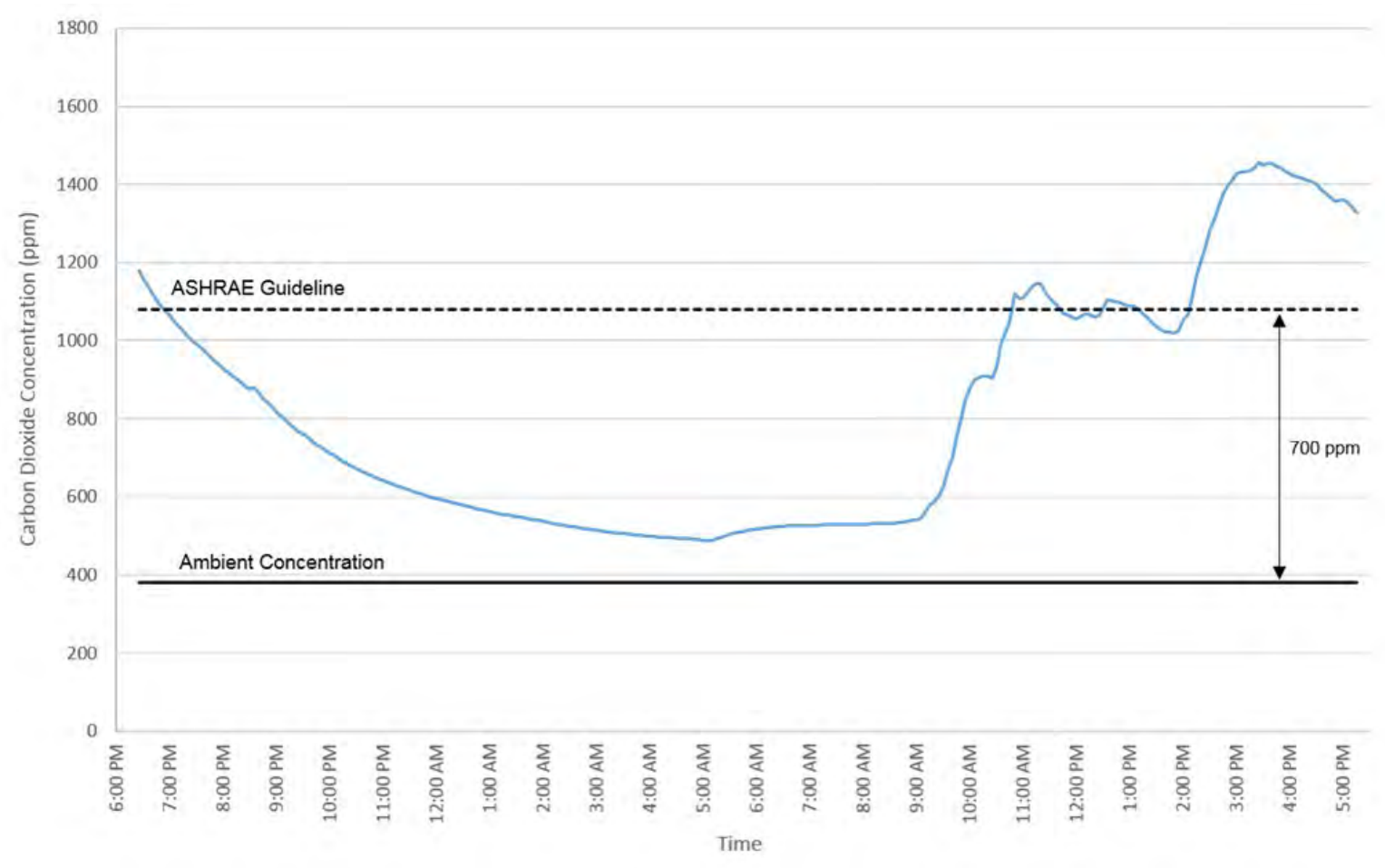

Figure 1. Carbon dioxide concentrations in courtroom H, November 16-17, 2015.

We compared the temperature and $\mathrm{RH}$ results to thermal comfort guidelines for summer and winter because this evaluation occurred in autumn (Table 1). The temperatures in all 14 areas checked were below the recommended thermal comfort guidelines of $75^{\circ} \mathrm{F}-81^{\circ} \mathrm{F}$ for summer, assuming a clothing insulation value of 0.5-1.0 (i.e., short-sleeve shirts/blouses, lighter weight clothing) [ANSI/ASHRAE 2013]. The temperatures in four of the 14 areas checked were not within the recommended thermal comfort guidelines of $68^{\circ} \mathrm{F}-77^{\circ} \mathrm{F}$ for winter, assuming a clothing insulation value of 1.0-1.3 (i.e., long-sleeve shirts/blouses, heavier weight clothing) [ANSI/ASHRAE 2013]. The temperatures in three of the 14 areas checked were below the recommended thermal comfort guidelines for summer and winter. The RH levels in all areas surveyed were within the recommended comfort guideline of less than $65 \%$ [ANSI/ASHRAE 2013].

\section{Ventilation Systems and Airflow Measurements}

Seven air handling units, located on the roof or in the basement, provided ventilation for the administrative and detention areas. None of the units had visible evidence of microbial growth. The pleated air filters $\left(16^{\prime \prime} \times 20^{\prime \prime} \times 2^{\prime \prime}\right.$ and $\left.20^{\prime \prime} \times 25^{\prime \prime} \times 2^{\prime \prime}\right)$ had a minimum efficiency reporting value of 8 . The filters appeared clean and properly installed in all air handling units except unit 4, which had a 1-inch gap between the air filters and the filter frame. The ventilation technicians at the building had upgraded computer controls on six of the seven air handling units in 2015 (the upgrade for unit 4, the remaining air handler, was scheduled). 
These upgraded controls allow the ventilation technicians to monitor and adjust the ventilation systems in real time, enabling them to quickly detect and respond to ventilation problems.

The building's ventilation design included variable air volume ventilation systems for offices and courtrooms and constant volume ventilation for the detention areas. Although we were informed that a recent ventilation test and balance report was available, the report could not be located. Additionally, the ventilation technicians did not have up-to-date building plans that accurately showed the ventilation system components or the design plans for the ventilation systems.

We measured airflow from ceiling diffusers on the lower level (child services), first floor (parentage), and second floor (judicial suite). We selected these locations based on our ability to identify the correct variable air box that was supplying air to the diffusers in each area, using the available building plans. We then asked the ventilation technicians to adjust electronically the air damper in the variable air volume box in each of the three areas to its open and closed setting. Because we did not have detailed ventilation information, we could not determine if the variable air volume boxes provided the appropriate amount of supply air as originally designed. We found the following:

- We measured no air from some ceiling diffusers after electronically adjusting the damper in the variable air volume distribution box to its closed position. The ceiling diffusers should provide a minimum amount of airflow even when the air damper is closed. This will reduce perceptions of stagnant or "stale" air.

- We measured similar air volumes from ceiling diffusers regardless of whether the air damper was open or closed. A properly operating variable air volume distribution box should provide a range of air volumes to ceiling diffusers.

Most restrooms that we checked with ventilation smoke tubes were under positive pressure in relation to the adjacent hallway, meaning that air flowed from these restrooms to surrounding areas. Restrooms should be kept under negative pressure to help keep odors from migrating into surrounding areas. We checked the supply airflow (the air coming into the room) and the exhaust airflow (air going out of room) in the following employee restrooms: records/clerk's office (lower level), intake (first floor), and judicial suite (second floor). We measured zero supply and exhaust airflow in these restrooms. Restrooms should be ventilated at all times. We measured about 50 cubic feet per minute of exhaust airflow in the public restrooms on the lower level and second floor, which is an acceptable ventilation rate for restrooms [ANSI/ASHRAE 2016].

Some of the staff offices in the detention side of the building were under negative pressure in relation to the juvenile inmate common areas, meaning that air flowed from the inmate areas and into the staff offices. The staff offices should be under positive pressure so that air moves from these areas and into inmate common areas. This ventilation design helps prevent the spread of airborne infections from inmates to building staff [Centers for Disease Control and Prevention 2006]. 


\section{Employee Interviews and Medical Record Review}

We interviewed 119 of 160 employees; 79 were female. The length of employment ranged from less than 1 year to 50 years. Sixteen employees had worked less than 1 year. The average tenure of the remaining employees was 19 years. Several employees reported the presence of rodents and rodent droppings in the building. Of the 119 interviewed employees, 65 reported no symptoms or medical conditions related to the building, and 54 reported symptoms or medical conditions that they felt were or might be related to the building. The most common reported symptoms thought to be related to the building were headache (14), sinus problems (13), worsening of allergic symptoms (10), eye irritation (8), and frequent upper respiratory infections (7). Symptoms or conditions reported by fewer than five people included fatigue, sore or dry throat, and cough. Seven employees reported having asthma, six of whom were diagnosed after beginning work at the building. Three of the seven reported their asthma symptoms were worse at work. Three additional employees reported symptoms consistent with asthma while at work. Medical records were requested for two of these employees; one did not seek medical care, and the symptoms have resolved.

Medical records were reviewed for two of three employees for whom they were requested. Records were not available for the third employee because of problems accessing them electronically at the health care facility. Neither of the records reviewed had evidence supporting a work-related condition.

Several employees reported conditions such as kidney stones, pyelonephritis (kidney infection), intestinal abscess, gallbladder disease, urinary tract infection, low folic acid, gastroesophageal reflux, and thyroid issues (hyperthyroidism, hypothyroidism, nodules, and cancer). None of these conditions is related to conditions or exposures in the building. Breast cancer had been diagnosed in eight current and former employees over an unknown time frame, and one employee each had been diagnosed with prostate cancer, thyroid cancer, and leukemia. These cancers are not related to the building either. Appendix A includes a detailed discussion of cancer and its potential relationship to the building.

\section{Discussion}

We typically do not recommend environmental sampling for chemical or biological contaminants in situations similar to those in this juvenile court and detention building. Sampling results are difficult to interpret because of (a) the absence of guidelines, (b) the ubiquitous presence of airborne chemical and biological materials, and (c) uncertainty about the relationship between low levels of contaminants and specific health effects. Therefore, measuring indoor environmental contaminants, in this instance hydrogen sulfide (sewer gas), volatile organic compounds, or mold, has seldom proved helpful in determining the cause of symptoms. However, we often measure ventilation and comfort indicators such as $\mathrm{CO}_{2}$, temperature, and RH to provide information about the functioning and control of heating, ventilating, and air-conditioning systems. We then compare these parameters to see if they are within applicable ANSI/ASHRAE guidelines for indoor environments. In mechanically ventilated and occupied spaces like this building we can also measure indicator pollutants 
such as $\mathrm{CO}_{2}$ (released by occupants) to provide information about the effectiveness of heating, ventilating, and air-conditioning systems.

One of the most common deficiencies we have found over many years of health hazard evaluations in nonindustrial indoor environments is inadequate ventilation. Inadequate ventilation may be due to the improper operation and maintenance of ventilation systems or from ineffective ventilation systems. In this building our findings indicate that the ventilation systems are ineffective. For example, temperatures in the occupied spaces that we checked were not always within the ANSI/ASHRAE recommended thermal comfort guidelines. Additionally, maximum $\mathrm{CO}_{2}$ concentrations exceeded the ambient outdoor $\mathrm{CO}_{2}$ concentration by at least 700 parts per million in several offices, indicating inadequate ventilation. An analysis of the published scientific literature showed that nonspecific symptoms such as headache, fatigue, and mucous membrane irritation increase as ventilation rates decrease [Fisk et al. 2009]. Studies in schools and office buildings have found decreased illness absence with increased ventilation rates [Mendell et al. 2011; Milton et al. 2000; Shendell et al. 2004]. Thus, improving heating, ventilating, and air conditioning operation and maintenance and increasing ventilation rates can improve symptoms without ever identifying any specific cause-effect relationships. We believe similar benefits would occur if ventilation is improved in this building.

The lack of a ventilation test and balance report, along with outdated and inaccurate building plans, hampered our ability to collect comprehensive airflow measurements. However, airflow measurements we made in child services, parentage, and the judicial suite areas showed that stagnant air conditions could develop when the dampers in the variable air distribution boxes were closed. In other instances we also found no difference in airflows from ceiling diffusers regardless of the damper setting (open or closed) in the variable air distribution box. Additionally, we measured no airflow (supply or exhaust) in many employee restrooms. These findings suggest a need for a comprehensive ventilation assessment of the entire building.

Regarding employee reports of exposure to raw sewage and sewer odors we learned from the maintenance staff of instances where detainees flushed objects such as clothing in the toilets to intentionally clog the sewage system. The building's sewage system is not equipped with grinder pumps. Although automatic trap primers were functioning at the time of our evaluation, this had not been the case in the past. Non-functioning trap primers could result in dry drain traps, allowing sewer odors to enter occupied spaces of the building. Building administrators and the maintenance staff were aware of the deteriorated cast iron waste lines beneath the slab foundation and had plans to identify, remove, and replace them once funding was obtained. Considering that the waste lines are beneath a concrete slab foundation it is less likely they were associated with sewer odors or sewage back-ups. It is more likely that the odors were from intentional clogging of the sewage system by detainees or from nonfunctioning trap primers.

The employees' symptoms that could be related to working in the building were headache, sinus problems, worsening of allergies, eye irritation, frequent upper respiratory infections, fatigue, throat irritation, and cough. These are common symptoms that we have frequently 
found in people working in buildings with poor ventilation. However, these symptoms can also be found frequently in the general population, and are associated with other causes as well. Of the general population, $86 \%-95 \%$ have one or more common symptoms during any given 2- to 4-week period, and the average adult reports a minimum of one symptom every 4-6 days [Barsky and Borus 1995]. Table 2 lists the general population prevalences of many of the symptoms reported by employees in this judicial building. In addition, the average adult has two to three upper respiratory infections per year [Benninger et al. 2003]. According to the National Health Interview Survey, $12 \%$ of U.S. adults reported physician-diagnosed sinusitis in 2012 [Centers for Disease Control and Prevention 2014]. Women were more likely to be diagnosed with sinusitis (15\% compared to $9 \%$ in men) [Centers for Disease Control and Prevention 2014]. Nonetheless, we have found that improving building ventilation often reduces the occurrence of many of these types of symptoms in building occupants.

Table 2. General population prevalence of symptoms similar to those reported by employees

\begin{tabular}{|c|c|c|c|}
\hline & $\begin{array}{l}\text { Clustered random } \\
\text { sample of households } \\
\text { in Australia }\end{array}$ & $\begin{array}{l}\text { General medical } \\
\text { practices in the } \\
\text { United Kingdom }\end{array}$ & $\begin{array}{c}\text { Representative sample } \\
\text { of general population of } \\
\text { New Zealand }\end{array}$ \\
\hline Participants & $n=3,016^{*}$ & $n=2,474 \dagger$ & $\mathrm{n}=1,000 \ddagger$ \\
\hline Time frame & 14 days & 14 days & 7 days \\
\hline $\begin{array}{l}\text { Number of symptoms } \\
\text { asked about }\end{array}$ & 12 & 25 & 46 \\
\hline $\begin{array}{l}\text { Percent reporting at } \\
\text { least one symptom }\end{array}$ & 80 & $>75$ & 89 \\
\hline $\begin{array}{l}\text { Number of symptoms } \\
\text { reported, mean (range) }\end{array}$ & Not reported & $3.6(0-22)$ & $5(0-36)$ \\
\hline $\begin{array}{l}\text { Symptoms similar to } \\
\text { those reported in this } \\
\text { building }(\%)\end{array}$ & $\begin{array}{c}\text { Stuffy nose (46) } \\
\text { Headache (33) } \\
\text { Unusually tired (30) } \\
\text { Cough (26) } \\
\text { Dry, itchy, or irritated } \\
\text { eyes (25) } \\
\text { Dry or sore throat (22) } \\
\text { Skin rash (12) }\end{array}$ & $\begin{array}{c}\text { Tired/run down (41) } \\
\text { Headache (39) } \\
\text { Sore throat (19) } \\
\text { Cough (18) }\end{array}$ & $\begin{array}{c}\text { Fatigue (36) } \\
\text { Headache (35) } \\
\text { Congested or runny } \\
\text { nose }(34) \\
\text { Cough }(28)\end{array}$ \\
\hline
\end{tabular}

${ }^{*}$ Reference: Heyworth and McCaul 2001

†Reference: McAteer et al. 2011

$\ddagger$ Reference: Petrie et al. 2014

The U.S. Environmental Protection Agency (EPA) conducted a systematic survey of 100 randomly selected office buildings without known IEQ complaints in the United States to develop baseline data about U.S. office buildings [Brightman et al. 2008]. The National Institute for Occupational Safety and Health (NIOSH) conducted a similar study of 80 buildings with IEQ complaints [Malkin et al. 1996]. Occupants in both studies reported work-related symptoms. The rank order of symptoms was the same, but rates were significantly higher in the buildings with IEQ complaints. The most common work-related symptoms reported in both studies were dry, itching, or irritated eyes; unusual tiredness or fatigue; headache; tension or irritability; pain in back, neck, and shoulders; stuffy or runny 
nose, or sinus congestion; sneezing; sore or dry throat; and difficulty remembering things or concentrating. Of the employees in the randomly selected buildings, $45 \%$ reported at least one work-related symptom. These common symptoms in the general population and in buildings are also among the most common symptoms reported by employees in this building.

Exposures that could be related to new-onset or worsening asthma include fragrances, dust mites, dander from rodents, and excrement of rodents and other pests such as cockroaches. Some allergens can be carried in on employees and visitors. The most common of these are cat and dog allergens, which can be an unrecognized source of allergic upper and lower respiratory and skin symptoms.

Several employees reported having medical conditions that we determined were unrelated to the building's conditions or exposures in the building. These medical conditions were also not due to any common exposure, nor spread from one person to another. These included cancer, kidney stones, urinary tract infection, gallbladder disease, low folic acid, gastroesophageal reflux disease, hypothyroidism, hyperthyroidism, thyroid nodules, and intestinal abscess.

\section{Conclusions}

We saw no evidence of a current mold or sewage problem in the building during our evaluation, and the underground diesel storage tank was being routinely inspected and properly maintained. However, we identified several correctable problems, in particular inadequate building ventilation and a lack of up-to-date building plans that the maintenance staff could use to help maintain the ventilation systems. Many of the symptoms employees reported, such as sinus problems and headaches, have been associated with damp buildings or inadequate ventilation but are also common in the general population. We found no evidence that other health problems reported by some employees, such as cancer, gallstones, and thyroid problems, were related to working in the building.

\section{Recommendations}

On the basis of our findings, we recommend the actions listed below to create a more healthful workplace. Our recommendations are based on the hierarchy of controls approach. This approach groups actions by their likely effectiveness in reducing or removing hazards. In most cases, the preferred approach is to eliminate hazardous materials or processes and install engineering controls to reduce exposure or shield employees. Until such controls are in place, or if they are not effective or feasible, administrative measures and personal protective equipment may be needed. 


\section{Engineering Controls}

Engineering controls reduce employees' exposures by removing the hazard from the process or by placing a barrier between the hazard and the employee. Engineering controls protect employees effectively without placing primary responsibility of implementation on the employee.

1. Hire a licensed professional mechanical engineer to do a comprehensive assessment of the building's ventilation systems. The engineer should have experience in the design of heating, ventilating, and air-conditioning systems for buildings that include multiuse areas such as offices, courtrooms, and detention centers.

2. Evaluate using grinders or screens to minimize or prevent sewage blockages.

3. Replace corroded cast iron waste pipes.

\section{Administrative Controls}

The term administrative controls refers to employer-dictated work practices and policies to reduce or prevent hazardous exposures. Their effectiveness depends on employer commitment and employee acceptance. Regular monitoring and reinforcement are necessary to ensure that policies and procedures are followed consistently.

1. Stop environmental sampling for chemical and biological agents to identify a cause for nonspecific symptoms among employees.

2. Establish a fragrance-free workplace policy. Ensure that it addresses perfumes and other scented personal care products, air fresheners, and potpourris.

3. Ask employees to report signs of moisture intrusion to the facilities maintenance staff. Establish a system for responding to requests and notifying the requestor what is being done and when the work is complete.

4. Form a labor-management health and safety committee to discuss the recommendations in this report and develop an action plan. Those involved in the work can best set priorities and assess the feasibility of our recommendations for the specific situation at the building.

5. Encourage employees with health concerns to seek evaluation and care from a physician who is residency-trained and board certified in occupational medicine and is familiar with the types of exposures employees might have had and their health effects.

Occupational medicine physicians can be found through a variety of sources, including the Association of Occupational and Environmental Clinics, at http://www.aoec.org/, and the American College of Occupational and Environmental Medicine, at http://www. acoem.org/. It may be useful to provide the physician with a copy of this report. 


\section{Appendix A: Evaluation of Cancer Clusters}

\section{Cancer}

Cancer is a group of different diseases that share the same feature of uncontrolled growth and spread of abnormal cells. Each different type of cancer may have its own set of causes. Cancer is common in the United States. In the United States, one in two men and one in three women will develop cancer over the course of their lifetimes. This does not include basal or squamous cell skin cancers, which are very common (more than 3 million diagnosed annually), or any in-situ carcinomas other than bladder. If these were included, rates would be even higher. One of every four deaths in the United States is from cancer. Among adults, cancer occurs more frequently with increasing age. Cancer cases may appear to occur with alarming frequency even when the number of cases is not more than would be expected in the general population because cancer is common, the population is aging, and more people are surviving cancer. This perception is especially common among a small group of people who have something in common with the cases, such as working in the same building.

Many factors play a role in the development of cancer. The importance of these factors varies for different types of cancer. Most cancers are caused by a combination of several factors. Some of the factors include (1) personal characteristics such as age, sex, and race; (2) family history of cancer; (3) diet; (4) personal habits such as cigarette smoking and alcohol consumption; (5) the presence of certain medical conditions; (6) exposure to cancer-causing agents in the environment; and (7) exposure to cancer-causing agents in the workplace. In many cases, these factors may act together or in sequence to cause cancer. Although some causes of various types of cancer are known, we do not know everything about the causes of cancer. One important point to note is that the absence of a risk factor does not mean there is no risk for developing cancer. For example, employees often say to us that they got breast cancer despite having no family history of breast cancer, so it must be due to their work. In fact, while having a first-degree relative with breast cancer increases one's risk of developing breast cancer, most people who get breast cancer do not have a family history of it.

\section{Breast Cancer}

Breast cancer is the most common cancer in women in the United States. Approximately 250,000 cases of invasive breast cancer will be diagnosed in women in the United States in 2016, not including 61,000 cases of carcinoma in situ [American Cancer Society 2016b]. One in eight women in the United States will develop breast cancer in her lifetime. Well-established breast cancer risk factors include family history of breast cancer, biopsy-confirmed atypical hyperplasia, early menarche (first menstrual period), late menopause, not having children or having the first child after age 30, overweight or obesity (especially after menopause), never breastfeeding a child, low physical activity levels, and higher levels of education and socioeconomic status [American Cancer Society 2016b; Weiderpass et al. 2011].

The International Agency for Research on Cancer (IARC) has classified alcoholic beverages of all types, in utero exposure to diethylstilbestrol, estrogen-progesterone oral contraceptives 
and hormone replacement therapy, and exposure to x-rays and gamma rays (types of ionizing radiation) as "carcinogenic to humans" with regard to breast cancer. The risk from ionizing radiation is highest if exposure occurs during childhood and is negligible if exposure occurs after age 40. IARC classifies digoxin, estrogen hormone replacement therapy, ethylene oxide, polychlorinated biphenyls, smoking, and shift work as "probably carcinogenic to humans."

While scientific studies have found an association between certain substances or occupations and breast cancer, the results are conflicting or unconfirmed. Some studies have found increased risk of breast cancer among nurses, librarians, laboratory technicians, telephone operators, glass manufacturing workers, textile workers, meat wrappers and cutters, printers, security personnel, scientific researchers, and hairdressers/cosmetologists, among others [Coogan et al. 1996; Gardner et al. 2002; Labrèche et al. 2010; Morton 1995; Peplonska et al. 2009; Shaham et al. 2006; Teitelbaum et al. 2003; Zheng et al. 2002].

Several studies have found teachers and other professional and managerial employees to have an increased risk for developing breast cancer [Bernstein et al. 2002; King et al. 1994; MacArthur et al. 2007; Pollán and Gustavsson 1999; Rubin et al. 1993; Snedeker 2006], but others have not [Calle et al. 1998; Coogan et al. 1996; Petralia et al. 1998]. No causative workplace exposures have been identified for these occupations, and it is postulated that the possible increase in risk is a result of non-occupational risk factors such as parity (number of times a woman has given birth), maternal age at first birth, contraceptive use, diet, and physical activity [MacArthur et al. 2007; Snedeker 2006; Threlfall et al. 1985]. Women with higher educational status are also more likely to have mammograms, thus increasing detection of breast cancer. Several studies have found that about one quarter to one third of invasive breast cancers detected by mammograms were overdiagnosed, i.e., would not have progressed or caused harm [Jørgensen and Gøtzsche 2009; Miller et al. 2014; Zahl et al. 2008].

\section{Cancer Clusters}

Cancers often appear to occur in clusters, which scientists define as a greater than expected number of cancer cases that occurs within a group of people in a geographic area over a defined period of time [Centers for Disease Control and Prevention 2012]. A cluster also occurs when the cancers are found among employees of a different age group or sex than is usual. A statistically significant excess of cancer cases may have a common cause, but can occur without a clear cause and can occur by chance [Aldrich and Sinks 2002; Thun and Sinks 2004]. In many workplaces the number of cases is small. This makes detecting whether the cases have a common cause difficult, especially when no apparent cancer-causing exposures are present. It is common for the borders of the "cluster" to be drawn around where the cases of cancer are located, instead of defining the population and geographic area first. This often leads to "clusters" that are not real. This is referred to as the "Texas sharpshooter effect" because the Texas sharpshooter shoots at the barn and then draws his bull's eye around the bullet hole.

When cancer in a workplace is described, learning whether the type of cancer is a primary cancer or a metastasis (spread of the primary cancer into other organs) is important. Only primary cancers are used to investigate a cancer cluster. To assess whether the cancers among 
employees could be related to occupational exposures, we consider the number of cancer cases, the types of cancer, the likelihood of exposures to potential cancer-causing agents, and the timing of the diagnosis of cancer in relation to the exposure. These issues are discussed below in a series of questions that relate to this request.

\section{Do employees at this building have more cancer than people who do not work at this building?}

No. Because cancer is a common disease, it may be found among people at any workplace. When several cases of cancer occur in a workplace they may be part of a true cluster when the number is greater than we expect compared to other groups of people similar in age, sex, and race. Disease or tumor rates, however, are highly variable in small populations and rarely match the overall rate for a larger area, such as the state, so that for any given time period some populations have rates above the overall rate and others have rates below the overall rate. Even when a higher rate occurs it may be consistent with the expected random variability. In addition, calculations like this make many assumptions that may not be appropriate for every workplace. Comparing rates without adjusting for age, sex, or other population characteristics assumes that such characteristics are the same in the workplace as in the larger population, which may not be true. However, general information on cancer rates is useful for providing perspective on the cancers in your population. The occurrence of 11 cases of cancer among over 150 employees over several years is not excessive. It is likely that many more current and former employees have been diagnosed with cancer than those who were reported to us, but the numbers and types of the reported cancers do not suggest a need for further case finding. As employees age, more cases of cancer (of many types) will appear.

\section{Do employees at this building have an unusual distribution of types of cancer?}

No. Cancer clusters thought to be related to a workplace exposure usually consist of the same types of cancer. When several cases of the same type of cancer occur and that type is not common in the general population, it is more likely that an occupational exposure is involved. When the cluster consists of multiple types of cancer, without one type predominating, then an occupational cause of the cluster is less likely. The 10 most common cancers in women are (in order): breast; lung and bronchus; colon and rectum; uterine corpus; thyroid; non-Hodgkin lymphoma; melanoma of the skin; kidney and renal pelvis; pancreas; and ovary. The 10 most common cancers in men are (in order): prostate; lung and bronchus; colon and rectum; urinary bladder; melanoma of the skin; kidney and renal pelvis; non-Hodgkin lymphoma; oral cavity and pharynx; leukemia; and pancreas. Several female employees in this building (where $66 \%$ of employees are female) have been diagnosed with breast cancer, the most common cancer among women in the United States. Three other of the most common types of cancer were also diagnosed among employees. 


\section{Is exposure to a specific chemical or physical agent known or suspected of causing cancer or other health effects occurring at this building?}

No. The relationship between some agents and certain cancers has been well established. For other agents and cancers, there is a suspicion of a link but the evidence is not definitive. When a known or suspected cancer-causing agent is present and the types of cancer occurring have been linked with these exposures in other settings, we are more likely to make the connection between cancer and a workplace exposure.

Office buildings rarely have hazardous exposures relevant to cancer. Asbestos can be a concern in older buildings, but it is known to cause lung cancer and mesothelioma, neither of which were reported among employees. Asbestos is not present in this building. Radon can be of concern in basement or lower floors of some buildings, but radon causes lung cancer, not other types of cancer. Radon monitoring is performed in the building every 2 years, and levels have been acceptable.

\section{Has enough time passed since exposure began?}

Latency is the time between first exposure to a cancer-causing agent and clinical recognition of the disease. Latency periods vary by cancer type but usually are a minimum of 10-12 years [Rugo 2004]. This issue is not relevant when considering the reported cancers at this building because there is not an excess of cancer among employees, the distribution of cancers is not unusual, and no exposures were associated with the cancers diagnosed.

In conclusion, the available evidence does not suggest that the reported cancers are associated with work at this building. The number and types of cancers are not unusual, and the reported exposures are not linked to the types of cancers reported.

The American Cancer Society estimates that about 171,000 cancer deaths in 2015 were caused by tobacco use alone. This is one third of all cancer deaths. It is well known that tobacco use increases the risk of cancer of the lung, mouth, nasal cavities, larynx, pharynx, esophagus, stomach, colorectum, liver, pancreas, kidney, bladder, uterine cervix, and ovary (mucinous), and myeloid leukemia [American Cancer Society 2016a]. There is limited evidence that tobacco smoking causes female breast cancer.

Another one quarter to one third of cancer deaths are due to poor nutrition, physical inactivity, overweight, and obesity [American Cancer Society 2016a]. Being overweight or obese is clearly associated with increased risk for developing cancer of the breast (in postmenopausal women), colon and rectum, endometrium, kidney, and pancreas, and adenocarcinoma of the esophagus. Obesity increases the risk of gallbladder cancer and possibly cancers of the liver, cervix, and ovary; multiple myeloma; non-Hodgkin lymphoma; and aggressive forms of prostate cancer [American Cancer Society 2016a]. 
Alcohol consumption is another modifiable personal risk factor that increases risk of cancer, in addition to the almost two thirds of cancer due to smoking, poor nutrition, physical inactivity, overweight, and obesity. Alcohol causes cancers of the mouth, pharynx, larynx, esophagus, liver, colorectum, and breast [American Cancer Society 2016a]. Even a few drinks weekly increase the risk of breast cancer.

Employees can take an active role in changing personal risk factors that are associated with certain types of cancer. The American Cancer Society posts general information about cancer on its website at http://www.cancer.org/ by clicking on "Learn about cancer." For information about a specific type of cancer, click on "Select a Cancer Type," select a type of cancer, then click "Go." 


\section{References}

Aldrich T, Sinks T [2002]. Things to know and do about cancer clusters. Cancer Invest 20(5-6):810-816.

American Cancer Society [2016a]. Cancer prevention and early detection facts \& figures 2015-2016. Atlanta, GA: American Cancer Society, http://www.cancer.org/acs/groups/ content/@,research/documents/webcontent/acspc-045101.pdf.

American Cancer Society [2016b]. Detailed guide: breast cancer. Atlanta, GA: American Cancer Society, http://www.cancer.org/cancer/breastcancer/detailedguide/.

ANSI/ASHRAE [2013]. Thermal environmental conditions for human occupancy. American National Standards Institute/ASHRAE standard 55-2013. Atlanta, GA: American Society for Heating, Refrigerating, and Air-Conditioning Engineers, Inc.

ANSI/ASHRAE [2016]. Ventilation for acceptable indoor air quality. American National Standards Institute/ASHRAE standard 62.1-2016. Atlanta, GA: American Society of Heating, Refrigerating, and Air-Conditioning Engineers, Inc.

ATSDR [1999]. Toxicological profile for hydrogen sulfide. Atlanta, GA: U.S. Department of Health and Human Services, Agency for Toxic Substances and Disease Registry.

Barsky AJ, Borus JF [1995]. Somatization and medicalization in the era of managed care. JAMA 274(24):1931-1934.

Benninger MS, Ferguson BJ, Hadley JA, Hamilos DL, Jacobs M, Kennedy DW, Lanza DC, Marple BF, Osguthorpe JD, Stankiewicz JA, Anon J, Denneny J, Emanuel I, Levine $\mathrm{H}$ [2003]. Adult chronic rhinosinusitis: definitions, diagnosis, epidemiology, and pathophysiology. Otolayngol Head Neck Surg 129(3 Suppl):S1-S32.

Bernstein L, Allen M, Anton-Culver H, Deapen D, Horn-Ross PL, Peel D, Pinder R, Reynolds P, Sullivan-Halley J, West D, Wright W, Ziogas A, Ross RK [2002]. High breast cancer incidence rates among California teachers: results from the California Teachers Study (United States). Cancer Causes Control 13(7):625-635.

Brightman HS, Milton DK, Wypij D, Burge HA, Spengler JD [2008]. Evaluating buildingrelated symptoms using the US EPA BASE study results. Indoor Air 18(4):335-345.

Calle EE, Murphy TK, Rodriguez C, Thun MJ, Heath CW [1998]. Occupation and breast cancer mortality in a prospective cohort of US women. Am J Epidemiol 148(2):191-197.

Centers for Disease Control and Prevention [2006]. Guidelines for preventing the transmission of Mycobacterium tuberculosis in health-care settings, 2005. Atlanta, GA: U.S. Department of Health and Human Services, Centers for Disease Control and Prevention, http://www.cdc.gov/mmwr/preview/mmwrhtml/rr5417a1.htm?s_cid=rr5417a1_e. 
Centers for Disease Control and Prevention [2012]. Cancer clusters. Atlanta, GA: U.S. Department of Health and Human Services, National Center for Environmental Health, http:// www.cdc.gov/nceh/clusters/about.htm.

Centers for Disease Control and Prevention [2014]. Summary health statistics for U.S. Adults: National Health Interview Survey, 2012. Atlanta, GA: U.S. Department of Health and Human Services, Centers for Disease Control and Prevention, National Center for Health Statistics, DHHS (NCHS) Publication No. 2014-1588, http://www.cdc.gov/nchs/data/series/ sr_10/sr10_260.pdf.

CFR. Code of Federal Regulations. Washington, DC: U.S. Government Printing Office, Office of the Federal Register.

Coogan PF, Clapp RW, Newcomb PA, Mittendorf R, Bogdan G, Baron JA, Longnecker MP [1996]. Variation in female breast cancer risk by occupation. Am J Ind Med 30(4):430-437.

Fisk WJ, Mirer AG, Mendell MJ [2009]. Quantitative relationship of sick building syndrome symptoms with ventilation rates. Indoor Air 19(2):159-165.

Gardner KM, Ou Shu X, Jin F, Dai Q, Ruan Z, Thompson SJ, Hussey JR, Gao YT, Zheng W [2002]. Occupations and breast cancer risk among Chinese women in urban Shanghai. Am J Ind Med 42(4):296-308.

Hathaway GJ, Proctor NH [2004]. Proctor and Hughes chemical hazards of the workplace, 5th edition. John Wiley and Sons, Inc., Hoboken, New Jersey.

Heyworth J, McCaul K [2001]. Prevalence of non-specific health symptoms in South Australia. Int J Environ Health Res 11(4):291-298.

Jørgensen KJ, Gøtzsche PC [2009]. Overdiagnosis in publicly organized mammography screening programs: systematic review of incidence trends. BMJ 339:b2587, http://dx.doi. org/10.1136/bmj.b2587.

King AS, Threlfall WJ, Band PR, Gallagher RP [1994]. Mortality among female registered nurses and school teachers in British Columbia. Am J Ind Med 26(1):125-132.

Labrèche F, Goldberg MS, Valois MF, Nadon L [2010]. Postmenopausal breast cancer and occupational exposures. Occup Environ Med 67(4):263-269, http://dx.doi.org/10.1136/ oem.2009.049817.

MacArthur AC, Le ND, Abanto ZU, Gallagher RP [2007]. Occupational female breast and reproductive cancer mortality in British Columbia, Canada, 1950-1994. Occup Med 57(4):246-253.

Malkin R, Wilcox T, Sieber WK [1996]. The National Institute for Occupational Safety and Health indoor environmental evaluation experience. Part two: symptom prevalence. Appl Occup Environ Hyg 11(6):540-545. 
McAteer A, Elliott AM, Hannaford PC [2011]. Ascertaining the size of the symptom iceberg in a UK-wide community-based survey. Br J Gen Pract 61(582):e1-11, http://dx.doi. org/10.3399/bjgp11X548910.

Mendell MJ, Mirer AG, Cheung K, Tong M, Douwes J [2011]. Respiratory and allergic health effects of dampness, mold, and dampness-related agents: a review of the epidemiologic evidence. Environ Health Perspect 119(6):748-756, http://dx.doi.org/10.1289/ ehp.1002410.

Miller AB, Wall C, Baines CJ, Sun P, To T, Narod SA [2014]. Twenty five year follow-up for breast cancer incidence and mortality of the Canadian national breast screening study: randomized screening trial. BMJ 348:g366, http://dx.doi.org/10.1136/bmj.g366.

Milton DK, Glencross PM, Walters MD [2000]. Risk of sick leave associated with outdoor air supply rate, humidification, and occupant complaints. Indoor Air 10(4):212-221.

Morton WE [1995]. Major differences in breast cancer risks among occupations. J Occup Environ Med 37(3):328-335.

Nordic Council of Ministers [2001]. From Nordic expert group: hydrogen sulphide, 127. The Dutch expert committee on occupational standards, Kristin Svenden.

Peplonska B, Stewart P, Szeszenia-Dabrowska N, Lissowska J, Brinton LA, Gromiec JP, Brzeznicki S, Yang XR, Sherman M, García-Closas M, Blair A [2010]. Occupational exposure to organic solvents and breast cancer in women. Occup Environ Med 67(11):722-729.

Petralia SA, Vena JE, Freudenheim JL, Marshall JR, Michalek A, Brasure J, Swanson M, Graham S [1998]. Breast cancer risk and lifetime occupational history: employment in professional and managerial occupations. Occup Environ Med 55(1):43-48.

Petrie KJ, Faasse K, Crichton F, Grey A [2014]. How common are symptoms? Evidence from a New Zealand national telephone survey. BMJ Open 4(6):e005374, http://dx.doi. org/10.1136/bmjopen-2014-005374.

Pollán M, Gustavsson P [1999]. High-risk occupations for breast cancer in the Swedish female working population. Am J Public Health 89(6):875-881.

Rubin CH, Burnett CA, Halperin WE, Seligman PJ [1993]. Occupation as a risk identifier for breast cancer. Am J Public Health 83(9):1311-1315.

Rugo H [2004]. Occupational cancer. In: LaDou J, ed. Current occupational and environmental medicine. New York: McGraw Hill Companies, Inc., pp. 229-267.

Shaham J, Gurvich R, Goral A, Czerniak A [2006]. The risk of breast cancer in relation to health habits and occupational exposures. Am J Ind Med 49(12):1021-1030.

Shendell DG, Prill R, Fisk WJ, Apte MG, Blake D, Faulkner D [2004]. Associations between classroom CO2 concentrations and student attendance in Washington and Idaho. Indoor Air 14(5):333-341. 
Snedeker SM [2006]. Chemical exposures in the workplace: effect on breast cancer risk among women. AAOHN J 54(6):270-279.

Teitelbaum SL, Britton JA, Gammon MD, Schoenberg JB, Brogan DJ, Coates RJ, Daling JR, Malone KE, Swanson CA, Brinton LA [2003]. Occupation and breast cancer in women 20-44 years of age (United States). Cancer Causes Control 14(7):627-637.

Threlfall WJ, Gallagher RP, Spinelli JJ, Band PR [1985]. Reproductive variables as possible confounders in occupational studies of breast and ovarian cancer in females. J Occup Med 27(6):448-450.

Thun MJ, Sinks T [2004]. Understanding cancer clusters. CA Cancer J Clin 54(5):273-290.

Van Aalst JA, Isakov R, Polk JD [2000]. Hydrogen sulfide inhalation injury. J Burn Care Rehab 21(3):248-253.

Weiderpass E, Meo M, Vainio H [2011]. Risk factors for breast cancer, including occupational exposures. Saf Health Work 2(1):1-8.

Zahl PH, Maehlen J, Welch HG [2008]. The natural history of invasive breast cancers detected by screening mammography. Arch Intern Med 168(21):2311-2316.

Zheng T, Holford TR, Taylor Mayne S, Luo J, Hansen Owens P, Hoar Zahm S, Zhang B, Zhang Y, Zhang W, Jiang Y, Boyle P [2002]. A case-control study of occupation and breastcancer risk in Connecticut. J Cancer Epidemiol Prev 7(1):3-11. 
Keywords: North American Industry Classification System 922110 (Courts), Tennessee, indoor environmental quality, IEQ, ventilation, hydrogen sulfide, mold, diesel 
This page left intentionally blank 
The Health Hazard Evaluation Program investigates possible health hazards in the workplace under the authority of the Occupational Safety and Health Act of 1970 (29 U.S.C. § 669(a) (6)). The Health Hazard Evaluation Program also provides, upon request, technical assistance to federal, state, and local agencies to investigate occupational health hazards and to prevent occupational disease or injury. Regulations guiding the Program can be found in Title 42, Code of Federal Regulations, Part 85; Requests for Health Hazard Evaluations (42 CFR Part 85).

\section{Disclaimer}

The recommendations in this report are made on the basis of the findings at the workplace evaluated and may not be applicable to other workplaces.

Mention of any company or product in this report does not constitute endorsement by NIOSH.

Citations to Web sites external to NIOSH do not constitute NIOSH endorsement of the sponsoring organizations or their programs or products. NIOSH is not responsible for the content of these Web sites. All Web addresses referenced in this document were accessible as of the publication date.

\section{Acknowledgments}

Desktop Publisher: Shawna Watts

Editor: Ellen Galloway

Logistics: Donnie Booher, Kevin Moore

Medical Field Assistance: Mary-Margaret Fill

\section{Availability of Report}

Copies of this report have been sent to the employer, employees, and union at the facility. The state and local health department and the Occupational Safety and Health Administration Regional Office have also received a copy. This report is not copyrighted and may be freely reproduced.

This report is available at http://www.cdc.gov/niosh/hhe/reports/pdfs/2015-0183-3255.pdf.

\section{Recommended citation for this report:}

NIOSH [2016]. Evaluation of indoor environmental quality and health concerns in a juvenile court building. By Page E, Broadwater K, Chiu S, Li JF, Burr G. Cincinnati, OH: U.S. Department of Health and Human Services, Centers for Disease Control and Prevention, National Institute for Occupational Safety and Health, Health Hazard Evaluation Report 2015-0183-3255, http://www.cdc.gov/niosh/hhe/reports/pdfs/20150183-3255.pdf. 
Delivering on the Nation's promise:

Safety and health at work for all people through research and prevention

To receive NIOSH documents or more information about occupational safety and health topics, please contact NIOSH:

Telephone: 1-800-CDC-INFO (1-800-232-4636)

TTY: 1-888-232-6348

CDC INFO: www.cdc.gov/info

or visit the NIOSH Web site at www.cdc.gov/niosh

For a monthly update on news at $\mathrm{NIOSH}$, subscribe to

$\mathrm{NIOSH}$ eNews by visiting www.cdc.gov/niosh/eNews. 